\title{
EXPERIENCE WITH THE HAMILTON AND HIGHMAN TEST FOR PARATHYROID HYPERFUNCTION IN CHRONIC NEPHRITIS, TOXIC GOITER, AND PAGET'S DISEASE OF BONE
}

\author{
BY D. ROURKE GILLIGAN, MARIE C. VOLK, AND S. L. GARGILL \\ (From the Medical Research Laboratories of the Beth Israel Hospital and the Department \\ of Medicine, Harvard Medical School, Boston)
}

(Received for publication April 29, 1938)

In 1932 Hamilton and Schwartz (1) described a method for the detection of small amounts of parathyroid hormone, three to five units, in preparations of the hormone and in blood. In 1936 Hamilton and Highman (2) presented certain modifications of this test designed to make the method particularly applicable to the detection of abnormally large amounts of parathyroid hormone in the blood of patients suspected of having increased parathyroid function. The test consists, briefly, in measuring the increase in the serum calcium of a rabbit at definite intervals after the rabbit has received an intramuscular injection of the blood or preparation containing parathyroid hormone, the animal being given amounts of calcium chloride solution by stomach tube at definite periods during the experiment.

In this communication we present our results obtained with the Hamilton and Highman test, and related blood chemical studies, in patients with chronic nephritis. The parathyroid glands of some of the patients were examined postmortem. Results obtained in toxic goiter and Paget's disease of bone are also briefly presented and discussed.

\section{REVIEW OF LITERATURE}

In the past six years Hamilton and his coworkers have applied this test to studies of the amounts of parathyroid hormone in the blood of experimental animals and of patients in whom hyperfunction of the parathyroid glands was suspected. These authors performed the test on the blood of 38 normal individuals; in these experiments the greatest rise in rabbits' serum calcium obtained in any experiment at either the three-hour or five-hour period after injection of the blood into the rabbits was $0.23 \mathrm{mM}$. per liter (2). These findings in normal individuals are used as a control basis; the finding of an increase of $0.30 \mathrm{mM}$. or more in the serum calcium of a rabbit is taken to indicate abnormally increased parathormone in the blood of a patient under study; the test is not applicable to the measurement of abnormally small amounts of circulating parathyroid hormone (2).
Hamilton and Schwartz (3) found evidences of increased parathormone in the blood, according to their test, in 9 of 12 rachitic rabbits. In this same communication the authors also reported that the blood calcium of the rachitic rabbits increased immediately and markedly when calcium chloride was administered to the animals by stomach tube, whereas there was a much more moderate rise in the calcium concentration in a series of normal rabbits so tested; the authors have since reported that these results could not be reproduced in other series of rachitic rabbits (4). In one patient with intractable rickets Highman and Hamilton found a positive test on two occasions (5) ; Kajdi and Shelling found a positive test in a case of florid rickets of several years' duration (6).

In a study of 74 pregnant women Hamilton, Dasef, Highman, and Schwartz found evidences of increased parathyroid hormone in the blood of 60 per cent of the cases studied between the fifth and seventh months of pregnancy (7). Only 3 of 13 women in the last two months of pregnancy showed positive tests; only 1 of 11 lactating women showed a positive test. This apparent increase in circulating parathyroid hormone during pregnancy accords with histological findings indicative of parathyroid hyperactivity $(8,9)$ and with the findings of Hoffmann et al. $(10,11)$, who demonstrated the presence in blood from pregnant women of a substance which behaves like parathyroid hormone. Hamilton et al. (7) point out that whereas increased parathyroid hormone was only occasionally found by their test in the blood of women in the tenth month of pregnancy, Hoffmann (10) found in this period the greatest amount of substance which acted like parathyroid hormone.

Highman and Hamilton found abnormally great amounts of parathyroid hormone in the blood of 20 of 23 patients with chronic nephritis and elevated blood urea nitrogen (12). Shelling and Remsen (13) reported a case of renal rickets with elevated concentrations of nitrogen and inorganic phosphorus in the blood, which case showed increased parathyroid hormone in the blood according to the Hamilton and Schwartz test, and at postmortem examination showed four markedly enlarged parathyroid glandules. These authors mention that the results of the Hamilton and Schwartz test were negative in other cases of renal rickets. Bass and Paxter (38) recently performed the "Hamilton test" on two occasions in one patient with renal rickets; on one of these occasions the result was "suggestively positive," on the other trial, negative. 
The present authors (14), in a preliminary communication, reported that 4 of 6 patients with thyrotoxicosis showed increased parathyroid hormone in the blood, according to the criteria of Hamilton and Highman.

Kajdi and Shelling (6) performed the Hamilton and Schwartz test in patients suffering from various skeletal diseases including Paget's disease, xanthomatosis ossium, the cases of renal rickets and the one with rickets mentioned above, and a case of osteitis fibrosa. The case of osteitis fibrosa, the one with rickets, and one of those with renal rickets showed increased blood parathyroid hormone; the other cases did not.

Hamilton and Schwartz have found a considerable variation in the magnitude of the serum calcium increase in different rabbits after a given amount of parathyroid has been injected (1). In the animals into which 1.5 or more units of parathormone per kilo were injected, however, the highest serum calcium values attained, either at the three-hour or five-hour period, were always greater than any occurring in control animals to which calcium chloride was given by stomach tube but to which no parathormone was administered. Dyer (15) has attempted to apply the test of Hamilton and Schwartz to the standardization of parathyroid extracts but concluded that the method was useful in detecting but not in quantitating small amounts of parathyroid hormone.

\section{METHODS}

Blood, both for the rabbit test and chemical studies, was drawn from patients who had fasted overnight in all instances in which blood chemical measurements were made.

The Hamilton and Highman test (2) for increased parathyroid hormone in the blood was performed exactly as described by the authors. A rise of $0.30 \mathrm{mM}$. per liter, or greater, in the calcium of the serum of a test rabbit either at the three-hour or five-hour period was considered a "positive" reaction. Certain details of the method were discussed with Dr. Hamilton through his kind cooperation in personal communication. Rabbits weighing from 1.5 to 4 kilos were utilized, most of the animals weighed from 2.5 to 3.5 kilos. No rabbit was utilized for a second test until at least three weeks after a previous test, whether the result had been positive or negative. The rabbits were fed Purina Rabbit Chow for several days or weeks before being used for the test. In 82 per cent of the animals the control calcium concentrations of the sera were from 2.8 to 3.4 (inclusive) $\mathrm{mM}$. per liter, the extreme limits for all animals being $2.4 \mathrm{mM}$. and $3.5 \mathrm{mM}$. per liter. In approximately 75 per cent of the experiments, sufficient blood was drawn from the rabbits to make duplicate measurements of the serum calcium on all three occasions of sampling; i.e., at the control, three-hour, and five-hour periods. It was noted rather frequently that the withdrawal of 10 cc. of blood on three successive occasions caused a considerable lowering of the hematocrit; it was presumed that lowering of serum protein also occurred and that this effect might occasionally mask a rise in the diffusible serum calcium. It was learned by personal communication from Dr. Hamilton that in his laboratory only sufficient blood for a single measurement of calcium was drawn at each period. We repeated the test in this manner in several patients in whom results had been negative previously when blood samples large enough for duplicate calcium measurements had been drawn; in each instance negative results were also obtained on these repeat trials.

The calcium concentrations of the sera of the rabbits and of the patients were measured according to Fiske and Logan (16), inorganic phosphorus concentrations of the sera according to Fiske and Subbarow (17). Plasma phosphatase measurements were made by the original method of Kay (18), by which method the upper limit of normal values in adults is 0.21 units. Nonprotein nitrogen was measured on the trichloracetic acid filtrate of the serum by the micro-Kjeldahl method. Total protein was measured by the macro-Kjeldahl method (19).

\section{RESULTS}

\section{Normal individuals}

The Hamilton and Highman test was performed in 5 instances in 4 normal adult subjects. The maximum increase in calcium of any of the test rabbits was $0.19 \mathrm{mM}$. per liter (Table I). The

TABLE I

Results of the Hamilton and Highman test in normal adults

\begin{tabular}{|c|c|c|c|}
\hline Case & Sex & Age & H. and $\mathrm{H} . *$ \\
\hline $\begin{array}{l}\text { 1. D. G...... } \\
\text { 2. M. V..... } \\
\text { 3. W. M. M } \\
\text { 4. G. L. . . }\end{array}$ & $\begin{array}{l}\mathbf{F} \\
\mathbf{F} \\
\mathbf{F} \\
\mathbf{M} \\
\mathbf{M}\end{array}$ & $\begin{array}{l}\text { years } \\
35 \\
35 \\
27 \\
25 \\
24\end{array}$ & $\begin{array}{c}\text { mM. per liter } \\
-0.26 \\
+0.19 \\
+0.19 \\
+0.08 \\
+0.08\end{array}$ \\
\hline
\end{tabular}

* "H. and H." refers to Hamilton and Highman in this table and in Table II; the figures in this column refer to the maximum rise in the serum calcium of the rabbit.

results in this small series accord with those found in 38 normal individuals by the authors of the method.

\section{Chronic renal insufficiency}

The test was performed in 19 instances in 15 patients with chronic renal disease (Table II). With the exception of 4 cases (Cases $4,12,13$, and 14) the patients were hospitalized because of uremic symptoms, including drowsiness, nausea, vomiting, muscular twitchings and cramps, and purpuric manifestations. Most of these hospital- 
TABLE II

Results obtained with the Hamilton and Highman test in patients with nephritis, together with pertinent blood chemical findings

\begin{tabular}{|c|c|c|c|c|c|c|c|c|c|c|}
\hline \multirow[b]{2}{*}{ Case } & \multirow[b]{2}{*}{ Sex } & \multirow[b]{2}{*}{ Age } & \multirow[b]{2}{*}{ Diagnosis } & \multirow{2}{*}{$\begin{array}{c}\text { Blood } \\
\text { pressure }\end{array}$} & \multicolumn{4}{|c|}{ Serum chemical findings } & \multirow{2}{*}{$\underset{\text { phosphatase }}{\begin{array}{c}\text { Plasma } \\
\text { ing }\end{array}}$} & \multirow[b]{2}{*}{$\mathrm{H} . \underset{\text { test }}{\text { and }} \mathrm{H}$. } \\
\hline & & & & & Calcium & $\begin{array}{l}\text { Phos- } \\
\text { phorus }\end{array}$ & Protein & $\begin{array}{c}\text { Non- } \\
\text { protein } \\
\text { nitrogen }\end{array}$ & & \\
\hline $\begin{array}{l}\text { 1. D. C. } \\
\text { 2. B. T. } \\
\text { B. T. } \\
\text { 3. R. M. } \\
\text { 4. R. S.. } \\
\text { 5. J. P.. } \\
\text { 6. E. S. } \\
\text { 7. J. Mc. } \\
\text { 8. B. M. } \\
\text { 9. L. M. } \\
\text { 10. A. F.. } \\
\text { 11. S. C.. } \\
\text { 12. A. W. } \\
\text { A. W. } \\
\text { A. W. } \\
\text { 13. L. H. } \\
\text { 14. M.C. } \\
\text { 15. B. B.. }\end{array}$ & $\begin{array}{l}\mathrm{M} \\
\mathrm{M} \\
\mathrm{M} \\
\mathrm{F} \\
\mathrm{F} \\
\mathrm{M} \\
\mathrm{M} \\
\mathrm{M} \\
\mathrm{F} \\
\mathrm{M} \\
\mathrm{F} \\
\mathrm{F} \\
\mathrm{F} \\
\mathrm{M} \\
\mathrm{M} \\
\mathrm{M} \\
\mathrm{F} \\
\mathrm{M} \\
\mathrm{F}\end{array}$ & $\begin{array}{c}\text { years } \\
35 \\
22 \\
22 \\
52 \\
44 \\
34 \\
34 \\
45 \\
40 \\
58 \\
40 \\
18 \\
18 \\
15 \\
15 \\
15 \\
53 \\
66 \\
10\end{array}$ & $\begin{array}{l}\text { Uremia } \\
\text { Uremia } \\
\text { Uremia } \\
\text { Uremia } \\
\text { Uremia } \\
\text { Uremia } \\
\text { Uremia } \\
\text { Uremia } \\
\text { Uremia } \\
\text { Uremia } \\
\text { Uremia } \\
\text { Uremia } \\
\text { Uremia } \\
\text { Renal rickets } \\
\text { Renal rickets } \\
\text { Renal rickets } \\
\text { Chronic nephritis } \\
\text { Chronic nephritis } \\
\text { Renal rickets }\end{array}$ & $\begin{array}{l}m m . H g \\
130 / 80 \\
160 / 80 \\
150 / 90 \\
160 / 100 \\
190 / 110 \\
160 / 90 \\
150 / 95 \\
142 / 84 \\
180 / 80 \\
170 / 90 \\
170 / 120 \\
120 / 60 \\
110 / 70 \\
240 / 130 \\
170 / 90 \\
120 / 70\end{array}$ & $\begin{array}{r}m g m . ~ p e r ~ \\
100 \text { cc. } \\
6.7 \\
8.4 \\
8.4 \\
5.0 \\
5.0 \\
5.6 \\
6.3 \\
6.3 \\
6.4 \\
6.4 \\
3.9 \\
4.0 \\
6.4 \\
8.5 \\
8.5 \\
8.8 \\
9.2 \\
10.0\end{array}$ & $\begin{array}{r}\text { mgm. per } \\
100 \text { cc. } \\
8.6 \\
7.0 \\
5.3 \\
13.1 \\
8.8 \\
10.9 \\
11.1 \\
9.9 \\
10.4 \\
9.7 \\
9.5 \\
9.1 \\
8.0 \\
7.0 \\
5.8 \\
4.3 \\
4.3 \\
7.6\end{array}$ & $\begin{array}{c}\text { grams per } \\
100 \text { cc. } \\
6.0 \\
5.8 \\
6.5 \\
5.5 \\
7.1 \\
7.7 \\
7.0 \\
5.5 \\
6.3 \\
5.3 \\
5.1 \\
5.8 \\
6.2 \\
6.7 \\
6.5 \\
7.7\end{array}$ & $\begin{array}{c}\text { mgm. per } \\
100 \text { cc. } \\
126 \\
96 \\
122 \\
263 \\
211 \\
271 \\
213 \\
107 \\
152 \\
124 \\
139 \\
195 \\
131 \\
126 \\
97 \\
79 \\
64 \\
113\end{array}$ & $\begin{array}{c}\text { Kay units } \\
0.11 \\
\\
0.19 \\
0.14 \\
0.10 \\
0.17 \\
0.19 \\
0.31 \\
0.19\end{array}$ & $\begin{array}{c}m M \text {. per } \\
\text { liter } \\
+0.07 \\
+0.08 \\
-0.06 \\
-0.20 \\
+0.07 \\
-0.11 \\
+0.08 \\
+0.10 \\
+0.47 \\
+0.17 \\
+0.01 \\
+0.22 \\
-0.06 \\
-0.11 \\
-0.18 \\
+0.26 \\
-0.25 \\
+0.08 \\
-0.20\end{array}$ \\
\hline
\end{tabular}

* Bodansky units.

ized cases died within a few weeks of the time of our studies. Usual therapeutic procedures were employed in these cases.

The nonprotein nitrogen of the serum was elevated in every case; the inorganic phosphorus was elevated in all but two cases (Cases 13 and 14). The protein of the serum was less than 6.5 grams per cent in 8 cases. The calcium of the serum of all cases was between 3.9 and $10.0 \mathrm{mgm}$. per $100 \mathrm{cc}$; the highest calcium value of $10.0 \mathrm{mgm}$. was found in a case with renal rickets (Case 15). ${ }^{1}$ In 10 of the 15 . patients the serum calcium was less than $7.0 \mathrm{mgm}$. per $100 \mathrm{cc}$; the two very lowest concentrations of calcium were found in patients with the lowest concentrations of serum protein. The phosphatase of the plasma was markedly elevated in the two patients with renal rickets (Cases 12 and 15); in one other case a somewhat elevated value was found (Case 9).

In 18 of the 19 experiments the Hamilton and Highman test was negative, the maximum rises in the calcium of the rabbits' sera at the threehour or five-hour periods being not greater than $0.30 \mathrm{mM}$. per liter. In three of these cases show-

1 This case was kindly referred to us by Dr. A. M. Butler of the Children's Hospital, Boston. ing negative results the test was repeated on one or more occasions; the repeat tests were likewise negative. In one patient (Case 8) the test was positive, the rabbit calcium increasing by $0.47 \mathrm{mM}$. above the control at both the three-hour and fivehour periods.

The parathyroid glands were examined postmortem in 4 of the patients who died in uremia (Table III); one of these cases had renal rickets (Case 12). In each instance the glands showed enlargement and hyperplasia of the "secondary" type (23) (Table III), the greatest hypertrophy being found in the patient with renal rickets. In all of these cases the parathyroid function test, performed from 1 to 4 months before death, was negative. In 2 of the 4 cases the concentrations of serum calcium were below $7.0 \mathrm{mgm}$. per $100 \mathrm{cc}$.

\section{Other clinical conditions}

During our investigations in patients with nephritis, we have also accumulated data on the results of the Hamilton and Highman test in a series of patients with Paget's disease, and a series with thyrotoxicosis.

The test was performed in 8 patients with ac- 
TABLE III

Parathyroid morphology in patients with chronic nephritis

\begin{tabular}{|c|c|c|c|c|c|c|c|c|c|}
\hline \multirow{2}{*}{ (as of Table II) } & \multicolumn{4}{|c|}{ Weight of glands } & \multirow{2}{*}{$\begin{array}{l}\text { Combined } \\
\text { weight of } \\
\text { glands }\end{array}$} & \multicolumn{4}{|c|}{ Measurements of glands } \\
\hline & $\begin{array}{l}\text { Left } \\
\text { lower }\end{array}$ & $\begin{array}{c}\text { Left } \\
\text { upper }\end{array}$ & $\begin{array}{l}\text { Right } \\
\text { lower }\end{array}$ & $\begin{array}{l}\text { Right } \\
\text { upper }\end{array}$ & & $\begin{array}{l}\text { Left } \\
\text { lower }\end{array}$ & $\begin{array}{l}\text { Left } \\
\text { upper }\end{array}$ & $\begin{array}{l}\text { Right } \\
\text { lower }\end{array}$ & $\begin{array}{l}\text { Right } \\
\text { upper }\end{array}$ \\
\hline $\begin{array}{l}\text { 1. D. C. } \ldots \ldots \ldots \ldots \\
\text { 2. B. T. } \ldots \ldots \ldots \ldots \\
\text { 11. S. C. } \ldots \ldots \ldots \ldots \\
\text { 12. A. W. } \ldots \ldots \ldots \ldots \ldots\end{array}$ & $\begin{array}{r}m g m . \\
113 \\
37 \\
34 \\
170\end{array}$ & $\begin{array}{r}m g m . \\
61 \\
85 \\
35 \\
132\end{array}$ & $\begin{array}{r}\text { mgm. } \\
150 \\
73 \\
37 \\
157\end{array}$ & $\begin{array}{c}\text { mgm. } \\
76 \\
21 \\
74 \\
36 \\
90\end{array}$ & $\begin{array}{l}\text { mgm. } \\
421 \\
269 \\
142 \\
549\end{array}$ & $\begin{array}{c}m m . \\
6 \times 7 \times 3 \\
5 \times 6 \times 3 \\
4 \times 3 \times 2 \\
11 \times 7 \times 5\end{array}$ & $\begin{array}{c}m m . \\
9 \times 5 \times 2 \\
11 \times 6 \times 3 \\
4 \times 3 \times 2 \\
10 \times 4 \times 2\end{array}$ & $\begin{array}{c}m m . \\
8 \times 6 \times 3 \\
10 \times 5 \times 2 \\
4 \times 3 \times 2 \\
11 \times 6 \times 4\end{array}$ & $\begin{array}{c}m m . \\
9 \times 4 \times 2 \\
3 \times 2 \times 1 \\
9 \times 4 \times 2 \\
4 \times 3 \times 2 \\
10 \times 4 \times 2\end{array}$ \\
\hline
\end{tabular}

\section{Microscopic findings}

Case 1: Cells in dense cords and masses, with tendency toward papillomatous and adenomatous arrangement in many areas. Slightly enlarged chief cells predominant, many showing considerable halo formation. Occasional greatly enlarged chief cells seen. Oxyphilic cells about normal in number; fat decreased. Left lower gland showed alveolus formation.

Case 2: Cells in dense cords and masses, with tendency toward papillomatous and adenomatous arrangement in many areas. Slightly enlarged chief cells predominant, many showing considerable halo formation. Oxyphilic cells increased in number; fat decreased.

Case 11: Findings same as in Case 2, except for slight increase in fibrous tissue in one gland.

Case 12:* Findings as in Case 2.

* Renal rickets.

tive Paget's disease. All of the cases showed clinical and roentgen ray findings typical of the disease, and markedly elevated plasma phosphatase values; all had more than one bone involved by the disease, most of them showing " generalized Paget's disease." The serum calcium, phosphorus, and protein concentrations were essentially normal. The Hamilton and Highman test was positive in 3 of the 8 cases, the rises in the calcium of the sera of the test rabbits in these instances being greater than $0.30 \mathrm{mM}$. In two cases in which the results were negative, the tests were repeated and again found negative.

The test was found positive in 7 of 18 patients with thyrotoxicosis. Of the first 7 patients studied, 5 showed a positive test, whereas in the last 11 cases only two tests were positive. In one case showing a positive result the test was repeated and again found positive. Two patients who showed positive results when thyrotoxic showed negative results after treatment with iodine and operation. The cases studied showed varying degrees of toxicity, some had received iodine for one to three days before the test was made. We have not discovered any characteristic differences in the clinical or laboratory findings between the patients who showed positive and those who showed negative tests. In 16 cases the bony calcification of the hands was compared with that of normal subjects of approximately the same ages by taking roentgenograms of both simultaneously. Slight osteoporosis was observed in this manner in one case; the parathyroid function test in this patient was positive. The plasma phosphatase was slightly increased in several patients; the result of the parathyroid function test was not related to the phosphatase values. Normal values for concentrations of calcium, phosphorus, and protein in the sera were found.

\section{DISCUSSION}

Enlargement of the parathyroid glands has been shown to occur frequently in patients with chronic renal insufficiency $(20,21,22,23)$. Among the most striking cases of this enlargement are those occurring in patients with renal rickets in whom chronic renal insufficiency is of a marked degree and of long duration $(13,24,25,26,27)$. This enlargement has recently been shown to be due primarily to a chief cell or " secondary" hyperplasia $(13,20,23,26,27)$; this hyperplasia, at times without apparent gross enlargement of the glands, occurs with regularity in all cases with chronic renal insufficiency of long duration (23). Enlargement of the parathyroids and "secondary" hyperplasia has been found in other clinical 
conditions such as rickets and osteomalacia (28, $29,30,31$ ) and occasionally in Paget's disease $(23,32,33)$.

Whereas all cases with parathyroid tumors and accompanying parathyroid hyperfunction, and cases with the "primary" or Wasserhelle type of hyperplasia probably show, eventually, characteristic blood chemical, clinical, and $x$-ray changes, osteitis fibrosa and increased serum calcium are encountered relatively with great rarity in patients with the " secondary" type of hyperplasia (23). Castleman and Mallory (23) feel that the occasional development of osteitis fibrosa in patients with renal insufficiency depends upon a long duration of the disease.

The chief purpose of the Hamilton and Highman test is to discover the presence or absence of parathyroid hyperfunction in cases which are suspected of having hyperfunction due to " secondary" hyperplasia. The test would, if reliable, clarify the relationship between anatomical findings in such cases, and function.

Our original purpose in studying the parathyroid function test in patients with chronic renal insufficiency was to compare, in the same subject, the results of the test with the degree of enlargement and hyperplasia of the parathyroid glands found at postmortem examination, in those cases in which autopsies could be made. It was thought that the meaning of the test would be clarified through such studies. These thoughts were formulated and some of our results obtained before publication of Highman and Hamilton's communication concerning the parathyroid function test in nephritis (12).

The negative results obtained with the test in 14 of our 15 patients with chronic renal insuffciency (Table II) are quite at variance with the positive results found by Highman and Hamilton in 20 of their series of 23 patients. In four of our cases showing no increased function by the test we were able to examine the parathyroid glands postmortem and found slight to marked enlargement, and hyperplasia of the " secondary" type in every case; the greatest enlargement was observed in a case of renal rickets (Case 12) (Table III). Presumably, varying degrees of parathyroid enlargement and hyperplasia were present in the other cases of our study as well. As was reported above, Kajdi and Shelling (6) found indications of increased parathyroid function by the Hamilton and Schwartz test (1) in one case with renal rickets and marked enlargement of the parathyroid glands. However, these authors (6), and Bass and Paxter (38) found negative results in other cases of renal rickets who presumably also had parathyroid hyperplasia. Two of the cases of our series had renal rickets, and both showed negative results with the Hamilton and Highman test ; postmortem examination in one of these cases revealed marked enlargement, with "secondary" hyperplasia, of the parathyroids.

Our series of nephritic cases accords with that of Highman and Hamilton (12) in that the patients had chronic nephritis and elevation of blood urea nitrogen. Most of our cases showed phosphorus retention and somewhat lowered plasma protein concentration; this is likewise true of Highman's series.

The concentrations of calcium in the sera of our nephritic cases were notably lower than those reported by Highman and Hamilton. The latter authors reported a serum calcium concentration below $8 \mathrm{mgm}$. per $100 \mathrm{cc}$. in only one of their series of 23 cases, whereas 10 of our 15 cases showed marked reduction in serum calcium concentration. Low calcium values have usually been found by others in patients with chronic nephritis and marked nitrogen and phosphorus retention $(23,34,35,36)$. Low serum calcium and enlargement of the parathyroids with " secondary" hyperplasia may, and usually do, coexist in chronic renal insufficiency, as shown by cases in our series and in those of Castleman and Mallory (23). It is worthy of note, in this connection, that in many of the reported cases of renal rickets, as well as in one of our cases (Case 15) with this condition, serum calcium values of 9.5 to $13 \mathrm{mgm}$. per $100 \mathrm{cc}$. have been found, in the presence of high serum concentrations of inorganic phosphorus and nitrogen $(13,26,27,38)$. As mentioned above, very marked degrees of " secondary" hyperplasia of the parathyroids are found in patients with this syndrome $(13,24,25$, $26,27)$.

It would appear from this discussion that in chronic renal insufficiency the results obtained with the Hamilton and Highman test are not reproducible in the hands of different investigators. 
It is also true that in our hands the test does not indicate increased parathyroid hormone in the blood of certain patients who have enlarged parathyroid glands showing the " secondary" type of hyperplasia.

That Hamilton and Schwartz were unable to reproduce their original results (4) showing marked increase in the serum calcium concentration of rachitic rabbits given soluble calcium salts by stomach tube, is disturbing, because of the similarity of the theory and the practice of this procedure with that utilized in the parathyroid function test. This finding suggests either some peculiarity of technique which was not reproduced in their second trial and in that of McCoy (see reference (4)), or the inconstancy of the response of different series of test animals (4). That the increases of serum calcium in individual rabbits differ considerably after a given dose of parathyroid hormone under the conditions of the Hamilton and Schwartz parathyroid function test has been recognized by Hamilton and Schwartz (1) and by Dyer (15); that large series of rachitic rabbits should vary inherently so importantly as to show consistent responses to calcium salts by stomach tube in individual animals within a series but quite opposite responses in other series is not understandable.

We have had no experience with the test in simple rickets or in pregnancy. As noted above we have found positive results in a certain percentage of cases with Paget's disease and cases with thyrotoxicosis. Our investigation in Paget's disease was prompted by the reported findings of enlargement and " secondary" hyperplasia of the parathyroid glands in certain individuals with this disease $(23,32,33)$; the investigation in thyrotoxicosis was undertaken on the suspicion that the parathyroids might become hyperactive in the presence of hyperthyroidism, and because of the osteoporosis occasionally observed in patients with thyrotoxicosis (37). Kajdi and Shelling (6) have reported a positive result in a patient with osteitis fibrosa cystica; they found negative results in a few cases with Paget's disease.

On the basis of present knowledge we feel that the significance of the test is not clear; it cannot be stated, therefore, whether those cases in whom we obtained positive results had a greater degree of functional hyperparathyroidism than those in whom negative results were found.

\section{SUM MARY}

1. Parathyroid hyperfunction was not indicated by the Hamilton and Highman test in 13 of 14 cases with chronic renal insufficiency.

These findings do not accord with the large percentage of positive results found with the same test in a similar series of nephritic patients by the authors of the test.

2. In 4 of the nephritic cases of this study with negative results, the parathyroid glands were found, at postmortem examination, to be enlarged and to show "secondary" hyperplasia. One of these patients had renal rickets.

3. It is pointed out that the serum calcium values reported by Hamilton and Highman in their series are notably higher than those found by us and others in most patients with advanced renal insufficiency and phosphorus retention.

4. The parathyroid function test was found positive in some patients with thyrotoxicosis and some with Paget's disease.

5. Because of the conflicting results obtained with the method by different investigators the significance of the test is, at present, questionable.

We are indebted to Dr. Mark D. Altschule for dissection and histological examination of the parathyroid glands described in this communication.

\section{BIBLIOGRAPHY}

1. Hamilton, B., and Schwartz, C., A method for the determination of small amounts of parathyroid hormone. J. Pharmacol. and Exper. Therap., 1932, 46, 285.

2. Hamilton, B., and Highman, W. J., Jr., A test for abnormally large amounts of parathyroid hormone in the blood. J. Clin. Invest., 1936, 15, 99.

3. Hamilton, B., and Schwartz, C., Rickets and hyperparathyroidism. Am. J. Dis. Child., 1933, 46, 775.

4. Hamilton, B., Absorption of ingested calcium in rachitic rabbits. Am. J. Dis. Child. (Correspondence), 1938, 55, 160 .

5. Highman, W. J., Jr., and Hamilton, B., Calcium and phosphorus metabolism in a case of intractable rickets. J. Pediat., 1936, 9, 56.

6. Kajdi, L., and Shelling, D. H., see Reference (13).

7. Hamilton, B., Dasef, Laura, Highman, W. J., Jr., and Schwartz, C., Parathyroid hormone in the blood of pregnant women. J. Clin. Invest., 1936, 15, 323. 
8. Seitz, L., Eklampsie und parathyreoidea. Arch. f. Gynäk., 1909, 89, 53.

9. Marine, D., The Thyroid, Parathyroids and Thymus. See: Cowdry, E. V., Special Cytology. Vol. II. Paul B. Hoeber, Inc. New York, 1932, 2d ed., p. 831.

10. Hoffmann, F., Utber die Darstellung und den Nachweis des Nebenschilddrüsenhormons im Schwangerenblut. Arch. f. Gynäk., 1933, 153, 181.

11. Hoffmann, F., and Rhoden, E., Untersuchungen über die Wirkung des Nebenschilddrüsenhormons aus Schwangerenblut. Arch. f. Gynäk., 1934, 156, 459.

12. Highman, W. J., Jr., and Hamilton, B., Hyperparathyroidism in kidney disease. J. Clin. Invest., 1937, 16, 103.

13. Shelling, D. H., and Remsen, D. Renal rickets. Report of a case showing four enlarged parathyroids and evidence of parathyroid hypersecretion. Bull. Johns Hopkins Hosp., 1935, 57, 158.

14. Gilligan, D. R., Gargill, S. L., and Volk, M. C., Parathyroid function in hyperthyroidism. Proc. Soc. Exper. Biol. and Med., 1936, 35, 89.

15. Dyer, F. J., The use of rabbits in the standardisation of parathyroid hormone. Quart. J. Pharm. and Pharmacol., 1935, 8, 197.

16. Fiske, C. H., and Logan, M. A., The determination of calcium by alkalimetric titration. II. The precipitation of calcium in the presence of magnesium, phosphate and sulfate, with applications to the analysis of urine. J. Biol. Chem., 1931, 93, 211.

17. Fiske, C. H., and Subbarow, Y., The colorimetric determination of phosphorus. J. Biol. Chem., 1925, 66,375 .

18. Kay, H. D., Plasma phosphatase. I. Method of determination. Some properties of the enzyme. J. Biol. Chem., 1930, 89, 235.

19. Dyer, B., Kjeldahl's method for the determination of nitrogen. J. Chem. Soc. Trans., 1895, 67, 811.

20. Bergstrand, H., Parathyreoideastudien. II. Utber Tumoren und hyperplastische Zustände der Nebenschilddrüsen. Acta med. Scandinav., 1921, 54, 539.

21. Pappenheimer, A. M., and Wilens, S. L., Enlargement of the parathyroid glands in renal disease. Am. J. Path., 1935, 11, 73.

22. Gilmour, J. R., and Martin, W. J., The weight of the parathyroid glands. J. Path. and Bact., 1937, 44, 431.

23. Castleman, B., and Mallory, T. B., Parathyroid hy- perplasia in chronic renal insufficiency. Am. J. Path., 1937, 13, 553.

24. Vogt, E. C., Renal rickets. Am. J. Roentgenol., 1933, 30, 624 .

25. Langmead, F. S., and Orr, J. W., Renal rickets associated with parathyroid hyperplasia. Arch. Dis. Childhood, 1933, 8, 265.

26. Smyth, F. S., and Goldman, L., Renal rickets with metastatic calcification and parathyroid dysfunction. Am. J. Dis. Child., 1934, 48, 596.

27. Price, N. L., and Davie, T. B., Renal rickets. Brit. J. Surg., 1937, 24, 548.

28. Erdheim, J., Quoted by Biedl, A.: Innere Sekretion. Part 1. Urban and Schwarzenberg, Berlin, 1913, $2 d$ ed., p. 108.

29. Pappenheimer, A. M., and Minor, J., Hyperplasia of the parathyroids in human rickets. J. Medical Research, 1921, 42, 391.

30. Hoffheinz, Utber Vergrösserungen der Epithelkörperchen bei Ostitis fibrosa und verwandten Krankheitsbildern. Virchows Arch. f. path. Anat., 1925, 256, 705.

31. Ritter, C., Utber Epithelkörperchenbefunde bei Rachitis und anderen Knochenerkrankungen. Frankfurt Ztschr. f. Path., 1920, 24, 137.

32. Ballin, M., Parathyroidism. Ann. Surg., 1932, 96, 649.

33. Shambaugh, P., and Cutler, E. C., Survival of an autoplastic parathyroid transplant in a patient without parathyroid deficiency. Arch. Surg., 1936, 32, 842.

34. de Wesselow, O. L. V., On the phosphorus and calcium of the blood in renal disease. Quart. J. Med., 1923, 16, 341.

35. Schmitz, H. W., Rohdenburg, E. L., and Myers, V. C., The inorganic phosphorus and calcium of the blood in nephritis. Arch. Int. Med., 1926, 37, 233.

36. Peters, J. P., and Eiserson, L., The influence of protein and inorganic phosphorus on serum calcium. J. Biol. Chem., 1929, 84, 155.

37. Aub, J. C., Bauer, W., Heath, C., and Ropes, Marion, Studies of calcium and phosphorus metabolism. III. The effects of the thyroid hormone and thyroid disease. J. Clin. Invest., 1929, 7, 97.

38. Bass, M. H., and Paxter, Jean, Congenital polycystic kidneys with secondary bone changes (renal hyperparathyroidism; renal rickets). J. Mt. Sinai Hosp., 1938, 4, 882. 